DOI: $10.14746 /$ por.2018.1.20

\title{
«ПОЛЬСКИЙ ЭЛЕМЕНТ» В КОЛОНИЗАЦИОННЫХ СТРУКТУРАХ ПОЗДНЕИМПЕРСКОЙ И РАННЕСОВЕТСКОЙ РОССИИ ${ }^{1}$
}

\author{
НАТАЛЬЯ СУвОРОвА ${ }^{2}$ \\ (Омский государственный университет им. Ф.М. Достоевского)
}

Keywords: Poles, identity, colonization expert, colonization structures, public service, career biographies.

Słowa kluczowe: Polacy, tożsamość, ekspert kolonizacji, struktury

kolonizacyjne, służba państwowa, biografia zawodowa.

\begin{abstract}
Natalia Suvorova, "POLISH ELEMENT" IN THE COLONIZATION STRUCTURES OF LATE IMPERIAL AND EARLY SOVIET RUSSIA. "PORÓWNANIA" 1 (22), 2018. Vol. XXII, P. 343-358. ISSN 1733-165X. In the article, on the basis of records and sources of personal origin, a "Polish element" is revealed in the colonial institutions of late imperial and early Soviet Russia. Taking into account the qualitative characteristics of a wider group - colonization experts, the author attempts to identify various additional factors, in addition to state policy and national preferences proper, the formation of hierarchies of identities in the group. Typologization in combination with the analysis of career biographies of officials of Polish origin allows us to reconstruct individual socio-cultural characteristics of the group, including socio-political sentiments, the level and nature of education, occupational diseases.
\end{abstract}

Abstrakt: Natalia Suvorova, «POLSKI ELEMENT»W STRUKTURACH KOLONIZACYJNYCH PÓŹNOIMPERIALNEJ I WCZESNOSOWIECKIEJ ROSJI. „PORÓWNANIA” 1 (22), 2018. T. XXII, S. 343-358. ISSN 1733-165X. W artykule na podstawie dokumentacji biurowej i źródeł pochodzenia osobistego autor ujawnia "polski element” w kolonizacyjnych instytucjach późnej imperialnej i wczesnej sowieckiej Rosji. Biorąc pod uwagę cechy jakościowe szerszej grupy - ekspertów kolonizacyjnych, autorka podejmuje próbę ujawnienia różnych dodatkowych czynników kształ-

1 Исследование выполнено при финансовой поддержке РФФИ, проект «Колонизационные эксперты между империей и советской властью» № 17-01-00446-ОГН.

2 E-mail: sng19911@gmail.com 
towania się hierarchii tożsamości w grupie, oprócz polityki państwa i właściwych preferencji narodowych. Typologizacja $\mathrm{w}$ połączeniu $\mathrm{z}$ analizą biografii zawodowych urzędników polskiego pochodzenia pozwala zrekonstruować indywidualne cechy społeczno-kulturowe grupy, w tym uczucia społeczno-polityczne, charakter edukacji, choroby zawodowe itp.

Государственной службе поляков в Сибири посвящен значительный комплекс научно-исследовательской литературы, в которой обозначены как отдельные личности, так и ведомства, разные уровни государственных структур, где наличествовали или даже преобладали чиновники польского происхождения (Матханова; Мулина 2012; Наумова 2008; Оплаканская 2003; Островский 2014: 92 - 158 и др.).

Целью данного исследования было выявление по личным документам, формулярным спискам, источникам личного происхождения поляков по происхождению в группе колонизационных экспертов второй половины XIX первой трети XX в. и сопоставление их характеристик с общегрупповыми; определение факторов, способствующих сохранению «польскости» в данной группе или напротив препятствующих/замещающих ее социальными или профессиональными идентификаторами. Полнота картины польского участия в сибирской истории требует включения не только «героических» биографий, но и вполне типичных карьерных траекторий тех, кто выбрал службу государству или народу, тех, кто разделял или напротив преследовал за передовые взгляды. Реконструкция различных польских «казусов», в том числе в рамках ограниченной группы колонизационных экспертов позволит дополнить конкретными фамилиями и карьерами польскую историю Сибири и выявить различные аспекты государственной и общественной активности поляков в Сибири; показать реакции чиновников и общественности на иноэтнические элементы в российском государственном аппарате.

Учитывая преемственность имперских и раннесоветских колонизационных структур для выявления, в том числе продолжающихся карьерных биографий, использовались личные дела и материалы по личному составу из фондов Переселенческого управления (RGIA (Rossijskij gosudarstvennyj istoricheskij arhiv). Ф. 391. Оп.7. (1896 - 1917)), Западно-Сибирского краевого управления исполнительного комитета Совета рабочих, крестьянских и красноармейских депутатов (GANO (Gosudarstvennyj arhiv Novosibirskoj oblasti). Ф. Р-209. Оп. 2. (1925 - 1931)); коллекция личных дел преподавателей и студентов Омского сельскохозяйственного института и фонда музея института (GIAOO Gosudarstvennyj istoricheskij arhiv Omskoj oblasti. Ф. 492. Оп.1). Эти документы дают представительный, хотя и не полный срез переселенческих учреждений. Наличие в личных делах автобиографий, личных листков, CV позволяют реконструировать групповые характеристики и получить динамичный образ колонизационного эксперта в условиях кардинальных соци- 
ально-политических изменений, зафиксировать меняющиеся и формирующиеся идентичности и мотивации.

Для выявления «польского элемента» в государственных колонизационных структурах помимо первичных источников (официальных делопроизводственных документов, мемуаров) привлекались пофамильные списки и биографические справочники (Mulina 2017; Ханевич и др.). Сложности поиска «польского» следа связаны с проблемой определения «польскости» и необходимостью сопоставления сведений из различных сложно сопоставимых источников. В официальных документах дореволюционного периода не фиксировалась национальность служащего, его родителей, супруги и детей. Частично разрешить этот вопрос позволяют метрические сведения, фиксирующие вероисповедание, место рождения, фамилии и имена посаженных родителей. Однако, соглашаясь с авторитетным мнением Л. Е. Горизонтова, вероисповедная принадлежность не обеспечивала автоматически польского самосознания, а православная вера детей не обязательно вытесняла национально-культурную ориентацию (Горизонтов 95 - 96).

Ряд колонизационных экспертов являлись «результатом» смешанных браков, поэтому место выхода отца, его статус (например, ссыльного), условно «польское» окружение на момент венчания и крещения детей не оставляло в официальных документах следов польскости, за исключением фамилии. Топограф Павел Петрович Здзеховский (1884 г.р.) происходил из дворянской семьи Минской губернии Павла Лаврентьевича и Неонилы Ивановны Здзеховских. Православное вероисповедание матери (Неонила Ивановна в девичестве Музыченко, дочь плац-адъютанта Ивана Кирилловича Музыченко) переходит к сыну. Поручителями брака Павла Петровича и девицы М. И. Подзываловой (православного вероисповедания) были со стороны жениха православный священник и потомственный почетный гражданин, а со стороны невесты турецкоподданный и русский потомственный дворянин. Эта постепенно усложняющаяся «интернациональность» окружающих землемера-топографа Здзеховского объясняется «кочевым» характером его службы: Амурская временная партия, строительная комиссия в Таврической губернии, присутствие по крестьянским делам Келецкой губернии, Курганско-Ялуторовская, Тюкалинская поземельно-устроительные партии. По завершению трехлетнего срока сибирской службы топограф Здзеховский ходатайствовал о переводе его с повышением должности и оклада в наиболее отдаленные места - Иркутский, Енисейский, Забайкальский или Туркестанские районы (RGIA. Ф. 391.Оп.7. Д. 1283. О службе топографа Павла Здзеховского).

Более распространенной является ситуация сохранения в брачной партии конфессионального единства и передаче этого же статуса детям. В метрической выписи из книги Новогрудского костела значатся родители Виктора Александровича Августовского Александр Викентьевич и Констанция и вос- 
приемники дворянин Иван Рафевич и Ядвига Захаржевская. Это был второй брак штатного сельского священника, и оба сына от этого брака имели римско-католическое вероисповедание. Окончив курс в Горы-Горецком училище и поступив на гражданскую службу в должности землемера низшего оклада, Виктор Александрович ходатайствовал о разрешении вступить в первый брак и выдаче, в связи с этим, пособия. Его избранницей стала девица Мария Эмильевна Рейхберг римско-католического вероисповедания (RGIA. Ф. 391. Оп. 1. Д. 14 «О службе землемера Амурской партии Августовского»).

Формулярные списки зафиксировали браки с православными, а материалы личных дел иногда дают сведения для подтверждения тезиса о «недолгих и неудачных браках» с православными (Леончик 312). Брак топографа Ивана Ивановича Дорожинского (из крестьян Виленской губернии, римско-католического вероисповедания) на крестьянке Александре Ивановне Лященко (православного вероисповедания) был зафиксирован в метрической книге причта Николаевской церкви села Кирилловка Мариупольского уезда в 1911 г. (RGIA. Ф. 391. Оп. 7. Д. 1074 «О службе топографа И. И. Дорожинского»). Прошения А. И. Лященко в Переселенческое управление (1914 г.) о поиске своего мужа, уехавшего в Сибирь, эмоционально и подробно фиксируют бытовую сторону мобильной службы низовых переселенческих чинов. Землемер Дорожинский в 1914 г. перевелся из Екатеринославской землеустроительной комиссии в г. Тару, «забыв» уведомить об этом молодую жену. Оставшаяся без средств существования женщина наводит справки в Переселенческом управлении и просит «повлиять на мужа словами», чтобы он «взял ее к себе, дал хоть 10 руб. в месяц или развод». Инспекторская часть Переселенческого управления, несмотря на увольнение Дорожинского из ведомства, уведомила покинутую супругу, о том, что ее муж состоит добровольцем роты Его Императорского величества 65 пехотного Московского полка.

Советские анкеты служащих предлагали многоуровневую национальную идентификацию кандидата, в том числе национальность, подданство, языковую принадлежность; национальную принадлежность родителей и жены. При этом преобладающие интернациональные настроения, а также корректирующиеся представления о «правильных» и не вполне «правильных» национальностях, очевидно, сдерживали проявления национальной самоидентификации, заставляя оговаривать ее политически более оправданными статусами: поляк, но принадлежу трудовому народу или потомственный интеллигент, потомок ссыльных. Служебные документы (как дореволюционные, так и советские) не фиксировали участие работника в благотворительных, религиозных, национальных организациях или общинах. Участие колонизационных экспертов в общественных, научных и профессиональных организациях показывает особые «переселенческие» площадки, объединяющие специалистов этой сферы: Императорское географическое общество, Общество Сельского 
хозяйства, профсоюз «Земли и леса» и др. Можно предположить, что в интеллигентской, «народнической» среде колонизационных экспертов преобладали не религиозные, а именно светские/общественные настроения и интересы. Ссыльный народоволец, статистик, чиновник Омской контрольной палаты Н. Я. Коншин, выражая настроения поколения, писал: «Нашим «Богом» сделался народ или точнее, крестьянство, которое мы идеализировали; «религией» стало будущее служение этому народу, теперь темному и забитому, но способному совершить великие перемены в мире» (Коншин 20).

В советских автобиографиях авторы в некоторых случаях отмечали свое отношение к сословному, классовому происхождению и национальной принадлежности. Интерес власти к этим вопросам порождает вполне очевидные опасения и желание оправдаться. Выстраиваемая государством иерархия наций корректировала, если не собственную национальность, то отношение к ней. Претендовать на место в советском аппарате выходцу из бедной еврейской семьи «последовательного бессребреника», желательно, с родителями бывшими ссыльными революционерами, было проще, чем поляку дворянского происхождения. Свои политические убеждения, а именно «симпатии к тем политическим группам и течениям, которые ставят своей целью благосостояние крестьянской трудовой массы, ее хозяйственное возрождение, культурное развитие и просвещение», Сигизмунд Гружевский в автобиографии объясняет разочарованием мелкобуржуазным окружением на родине, узкими взглядами и интересами родственников и сослуживцев (GANO. Ф. Р-209. Оп. 2. Д. 129. Гружевский Сигизмунд Альфонсович). Неоднократно упоминая Родину в автобиографии, Гружевский себя поляком не называет, заканчивая польскую родословную на своем отце, «который считал себя поляком и происходил из дворянской семьи». Женитьба на «крестьянской девице» окончательно закрепляет новое социальное и, по всей видимости, национальное состояние автора - «свыкся и сроднился с сельским населением, а связь с родиной потерял».

В современных биографических справках и указателях национальная принадлежность если и оговаривается, то зачастую без уточнения и аргументации или со ссылкой, например, на древние родовые корни, возможно, даже не вполне известные самому персонажу. Существенные методологические и идеологические расхождения в понимании национального статуса, а также разновекторные интересы (формирующихся государственных образований, научных школ, партийно-политических течений и др.) приводят к «присвоению» одного и тоже персонажа одновременно к разным нациям или «сохранению» национально неопознанных героев.

Формирование группы колонизационных экспертов начинается во второй половине XIX в. в связи с массовым характером переселения, формированием местных переселенческих структур и распространением специального образования. Народничество как идеология и общественно-политическое течение 
не просто оправдывало, а увлекало, создавало романтическое восприятие работы в аграрной сфере, как оправданной служением народу, общему делу, а не государству. Переселенческое дело было близко с земскими службами, где трудились, по сути, не мундирные чиновники, а служили народу интеллигенты. Переселенческие чиновники и сотрудничавшие с ними лица, совместно действуя в научных и просветительских обществах, а также в инициированных государством экспедициях по изучению географических, хозяйственных и демографических условий колонизации, формировали новую общественную среду с особым этосом. Это отдаляло их от местного полицейско-административного аппарата, помогало интегрироваться, хотя бы некоторым, в общий поток интеллигенции. Новые стандарты поведения с одной стороны задавались высшими управленцами переселенческого ведомства, а с другой закреплялись демократическими слоями местных переселенческих учреждений, в том числе из ссыльных.

Можно отметить особое отношение в колонизационной среде к национальным вопросам. Обострение национальных проблем в Российской империи, формирующийся русский национализм, тем не менее, находили весьма слабое проявление в профессиональной среде переселенческих чиновников. Русский национальный сценарий колонизации Сибири рассматривался по преимуществу как проект политический. На практике же первоочередной задачей считалась «помощь в переезде и устройстве на новом месте крестьян, не справившихся с хозяйственным кризисом на родине и способствование экономическому развитию Сибири» (Татищев 43). Национальные приоритеты в переселенческом деле, будь то русские, сибирские или инородческие, один из признанных колонизационных экспертов А. А. Кауфман определял как узкокорыстные. В «русском крестьянине переселенце» он мог разглядеть «таежника или трудолюбивого латыша и белоруса и ... ростовщика или бродячего «кустанайца» (Кауфман 26). Размышляя о болезненном «культурном бессилии» русской колонизации, Кауфман аргументировал данный тезис симптомами слабости «российского» хозяйства, приемов, культур. Это отношение к национальным характеристикам находит также отражение и в языке описания экспертов сибирского старожильческого и переселенческого населения. Классическим образцом обследования хозяйств колонизуемой азиатской территории были труды экспедиции А. Ф. Щербины, в которых основными категориями населения были социальные и имущественные страты: переселенец-пролетарий, представитель киргизской плутократии с количественными параметрами обеспечения землей, скотом, семенами.

По мнению русского националиста и монархиста В. Ф. Романова, не только среди чиновников землеустроительного ведомства, но вообще для современной ему молодежи были характерны преимущественно интернациональные ценности, считавшей национализм «чем-то вроде дурного тона». В этом 
плане он противопоставлял индифферентную «нашу молодежь» окраинной, и особенно польской, для которой была характерна «горячая любовь к своей Родине, национализм» (Романов 60).

Основная часть колонизационных экспертов польского происхождения, сведения о которых удалось собрать, принадлежала к «молодому поколению» 1870-1890-х гг. рождения. Сведения о единичных представителях экспертов «среднего поколения» 1840 - 1860-х гг. рождения: Мечислав Станиславович Старыческий (1849 г.р.), Адам Фелексович Кублицкий-Пиоттух (1855 г.р.), Витольд Крживицкий (1860 г.р.), Иван-Стефан Матвеевич Жебровский (1862 г.р.), Николай Викентьевич Биллевич (1861 г.р.). пока недостаточны для обобщений. Отрывочность сведений объяснима отсутствием до конца XIX в. систематизированных сведений по чиновникам, занимающихся переселенческим делом.

До 1880-х - 1890-х гг. в связи с незначительными масштабами переселения оставались неразвиты и местные переселенческие структуры. Польским ссыльным - участникам восстания 1863 г. в качестве поприща государственной службы определяли, прежде всего, медицину и канцелярию (Ремнев 1996). «Природные поляки» особенно на высоких государственных должностях вызывали опасения, усиливающиеся и подпитывающиеся близкими по времени событиями польского восстания и массовой ссылки.

Достаточно широко представленный «польский элемент» в переселенческих структурах конца XIX - начала XX вв. оправдан появлением значительного числа вакансий в ведомстве. Переселенческие структуры с конца 1880-х гг. активно развивали местные учреждения, привлекая на службу кандидатов, имеющих соответствующий образовательный ценз. Изменения в сфере образования в 1890-х гг. привели к созданию специализированных сельскохозяйственных учебных заведений (земледельческие и землемерные училища, сельскохозяйственные институты, Горы-Горецкие земельно-таксаторские классы), выпускники которых активно занимали переселенческие вакансии в центре и на местах. Уже на этапе обучения будущих колонизационных экспертов польского происхождения можно отметить широкую географию образовательного пространства (от Москвы и Санкт-Петербурга до Уфы и Казани) и разнообразные направлений подготовки: от «классических» аграрных и юридических до модных - естественно-научных, экономических. Учебные заведения на территории западных губерний (Варшавский университет, Виленское городское училище, Рижская городская гимназия) и Сибири (Алтайское горное училище, Томское реальное училище, Томский университет) предопределяли наиболее распространенные варианты попадания на сибирскую службу поляков: либо это чиновники из Западных губерний ради продвижения по службе, либо поляки местного «сибирского происхождения», в том числе потомки ссыльных. Аграрные специальности (агроном, межевщик, 
ветеринар), так же как и выпускники естественного или юридического отделений университета рассматривались как начальная теоретическая ступень подготовки. Технические специалисты, только получив практический опыт работы, в том числе самостоятельной, могли претендовать на административные, управленческие вакансии.

Аграрная сфера, в сравнении, например, с инженерным делом, не считалась особо материально выгодной, что дополнительно снижало конкуренцию. Ведомство предлагало льготы и повышенное жалование для чиновников и вольнонаемных работников, переезжающих в отдаленные губернии. Наиболее распространенной мотивацией в заявлениях кандидатов (и не только польского происхождения) указывалось повышение чина и жалования, невозможность карьерного роста и высокооплачиваемой службы на родине. Сугубо карьерные и материальные соображения изредка корректировались и дополнялись упоминанием особого характера службы в переселенческом ведомстве - не канцелярского, «живого», плодотворного. В. Ф. Романов, будучи сам представителем переселенческого ведомства писал, что землемеры и агрономы «работали идейно, ... на службу не смотрели как на средство наживы» (Романов 155). В общественной, и тем более внутренней корпоративной среде считалось недопустимым зарабатывать помимо жалования на обездоленном крестьянине, обращать сэкономленные по службе средства в собственный капитал или получать процентное вознаграждение за работы. Привычными, в том числе в прессе, были сведения о потраченных переселенческими чиновниками не только казенных, но и собственных средствах на крестьянские пособия. Учитывая массовый набор чиновников, народническая романтика будет постепенно отходить на второй план, но даже в заявлениях о поступлении в советские переселенческие учреждения «старорежимное» «служение делу» будет иногда упоминаться. В 20-е гг. XX в., например, у советских работников сохраняется особое отношение к переселенческой службе, как «живой работе». В заявлении Владислава Станиславовича Генделя о назначении на должность заведующего переселенческой партией отмечалось, что руководство переселенческой партией предпочтительней «узко канцелярской работе по водворению» и не диктуется материальными соображениями (GANO. Ф. Р-209. Оп. 2. Д. 3. Документы (списки, анкеты, автобиографии, переписка) по личному составу сотрудников управления зав. колонизацией Сибири. Л. 67). Претендентов интересует работа, где можно максимально проявить «инициативу и энергию». Идеальные качества советского переселенческого служащего вполне соответствовали «старорежимным колонизаторам», включая антибюрократические и неканцелярские черты. Требования, предъявляемые к переселенческому персоналу разного уровня (знакомство с местными условиями сельского хозяйства, Земельным кодексом, ... со всеми основными законами СССР и ... до некоторой степени подготовленность к общественной 
работе»; честность, работоспособность, энергичность, достаточный образовательный ценз и довольно широкий кругозор), постепенно формализуются, подменяются клишированными фразами, пригодными для характеристики «советского работника» вне зависимости от сферы деятельности. «Худшие стороны» специалиста советского аппарата землеустройства: чрезвычайная грубость, чиновничье отношение к крестьянам, «голое ничем не прикрытое стремление «сорвать», где только можно, индифферентное отношение к делу, ... доходившее до преступной халатной волокиты»; «излишнее самомнение, неуживчивость, недостаточная товарищеская спайка с сослуживцами» - представляют полный и весьма разнообразный набор бюрократических элементов (GANO. Ф. Р-209. Оп. 2. Д. 12).

В условиях традиционной для азиатских окраин бедности профессиональных кадров, местные переселенческие учреждения пополнялись не вполне благонадежными с точки зрения государства служащими, в том числе политическими оппонентами, ссыльными. B конце XIX - начале XX в. в переселенческих структурах нашли прибежище для службы очень разнообразные по идейной и политической направленности группы, но очевидно, с преобладанием демократически настроенной молодежи. Демократической и даже оппозиционно-радикальной этой среду делали политические ссыльные, которые спешили пристроить своих друзей «по несчастью», создавая на местах в переселенческих структурах политические «кружки по интересам»). В анонимном доносе министру земледелия и государственных имуществ в 1906 г. отмечалось, что «местная переселенческая организация не может считаться в политическом отношении вполне благонадежной, так как в ее среде есть, безусловно, лица, политически весьма подозрительные» (RGIA. Ф. 391. Оп. 5. Д. 278. О неблагонадежных чиновниках местных переселенческих организаций. Л. 79). Подробно характеризуя личный состав переселенческой канцелярии, доноситель пришел к неутешительному выводу, что это и «не канцелярия, а сброд всевозможных гадко-пошлых людей, социалистов революционеров, гнездо змеиное, грозящее всем не примыкающим к их партии» (Там же. Л. 81). Руководители переселенческого ведомства по мере возможности отстаивали свои и без того незначительные кадры перед департаментом полиции и оправдывали их политическую неблагонадежность профессионализмом и бескорыстностью.

Поиск «враждебных элементов», «внутренних врагов» в государственных учреждениях проводился российским обывателем не только по политическим критериям неблагонадежности, но и по национальным. Военное время усиливало фобии в отношении чиновников с немецкими фамилиями (Алишина 16). Традиционно политически опасными считались в общественном мнении чиновники еврейского и польского происхождения. Показательна история «вычисления» известным журналистом «Нового времени» М. Меньшиковым 
польского происхождения заведующего переселенческим делом в Приморской области С. П. Шликевича и обвинения его на этом основании «чуть ли не в государственной измене», «умышленном торможении заселения Уссурийского края», «сношениях с Японией» (Романов 160). «Корпоративным адвокатом» Шликевича выступил коллега по переселенческому ведомству В. Ф. Романов. Определив Шликевича, как «глубокого патриота», который «борется за каждую пядь земли в интересах русского крестьянства», в качестве доказательства поясняет, что Шликевич «никогда поляком не был», но являлся дворянином Курской губернии. Романов заметил, что и в среде польских чиновников на российской службе встречаются «высоко честные и благородные единицы» (в качестве примера, приводит управляющего отделом В. И. Масальского, который «вел дело безупречно честно и был искренне предан ему), но легче им таковыми быть все же у себя в родной стране.

Процедуры формирования местных переселенческих структур, особенно в отношении вольнонаемных сотрудников, предполагали достаточно высокую степень самостоятельности руководителей партий и экспедиций. Помимо профессиональных качеств, дополнительными критериями отбора кандидатов могли стать совместная предшествующая служба, общность общественно-политических взглядов или родственные связи и знакомства. Факты приема на службу из числа своих соотечественников, родственников зафиксированы исследователями в различных ведомствах, в том числе и переселенческом (Горизонтов 65; Островский 142) Причем эта ситуация являлась характерной и для дореволюционных, и для советских учреждений.

При устройстве на службу в Сибири в Российско-Азиатское товарищество в 1904 г. С. А. Гружевский пользуется «польскими связями», в том числе знакомством со «старым повстанцем 63 г., ... с которым изредка поддерживал переписку» и политическими ссыльными (Ващлав Нелепец, Григорий Цвилинг и др.) (GANO. Ф. Р-209. Оп. 2. Д. 129). Сблизившись с этими и другими сослуживцами-ссыльными и оказавшись в «революционный 1905 год» замешанным во «враждебной, революционной» деятельности Сигизмунд Альфонсович при поддержке одного из хозяев Черемховских копей (И. И. Собещанского) получает новую работу. Как уполномоченный товарищества он командируется в Амурскую область. Находясь в статусе лица, заподозренного в участии в революционном движении, с запрещением пребывания на территории Иркутской губернии, он устраивается производителем работ по землеустройству и отводу переселенческих участков. Свое трудоустройство на государственной службе Гружевский объяснил наличием множества вакантных должностей в переселенческом ведомстве, необходимым образовательным цензом и отсутствием бдительности местных жандармских властей или отсутствием интереса к «такой категории неблагонадежных». Дослужившись до должности заведующего подрайоном до революции, в 1925 г., после непродолжительной 
службы при Колчаке мировым судьей, Гружевский продолжает достаточно успешную карьеру в переселенческом ведомстве, в том числе при содействии исполняющего должность заведующего партией Н. Ф. Жизневского («внук повстанца 1861 г.») и заведующего технической частью М. И. Леманского (GANO. Ф. Р-209. Оп. 2. Д. 129. Л. 1.).

Переселенческие структуры в условиях войн и социальных катаклизмов продолжают активную деятельность. Уже в годы Первой мировой войны, сменив контингент (переселенцев на беженцев, военнопленных), сократив исследовательскую составляющую, Переселенческое управление сохранило кадры и структуру. По мере возвращения к мирной деятельности и провозглашения «восстановления народного хозяйства», новые правительства возвращаются к прежним колонизационным идеям, причем их реализация остается в руках «старых» специалистов (Моисеенко 87 - 141; Рынков 108 - 137).

В условиях Гражданской войны начинается строительство новой научной школы, цель которой - подготовка «колонизаторов широкого профиля». Одним из организаторов сибирского колонизационного образования стал Н. А. Сборовский. В своей советской автобиографии Н. А. Сборовский, ломая представления о сословном прошлом и классовом настоящем, отмечал, что происходит из семьи потомственных русских интеллигентов. Духовное звание деда, чиновная карьера отца (в горном ведомстве дослужился до действительного статского советника) последовательно сочетались с преподавательской и научной работой. Уже А. А. Сборовский - отец Николая Александровича, сотрудничал с ИРГО, составляя материалы для изучения горного дела в степных областях Западной Сибири (Казак). По стопам отца Николай Александрович поступает в Горный институт, а после вместе с отцом приезжает в Омск, где принимает активное участие в научно-исследовательской и общественно-политической жизни. С началом массового переселения административный столичный статус Омска подкрепляется ролью координационного, научно-исследовательского, образовательного и экспедиционного центра колонизации азиатских окраин. Город чиновников и военных, обывателей наполняется новой, общественно и политически активной публикой. При этом именно «переселенческие площадки», в виде учреждений государственной и общественной помощи крестьянам-переселенцам, сельскохозяйственных и лесных складов, исследовательских экспедиций содействовали если не объединению, то совместной деятельности чиновников разных уровней и ведомств и интеллигенции, редко местной, провинциальной, чаще ссыльной. Учитывая общественно-политические взгляды Н. А. Сборовского, его участие в «Союзе борьбы за освобождение рабочего класса», пропагандистскую активность, внушительный список арестов и приводов, то перспективы его деятельности были практически предопределены. Он становится корреспондентом «Степного края», сотрудником экспедиции по исследованию Степных областей, 
принимает участие в разработке статистических материалов «О движении землевладения в России». Опыт сотрудничества (работы корреспондентом, журналистом) пригодится ему в советской Сибири. В 1922 - 1928 гг. Сборовский участвует в создании и служит в качестве редактора известного ежемесячного научного журнала Сибревкома эпохи НЭПа «Жизнь Сибири». Предосудительный формуляр не помешает Н. А. Сборовскому принимать активное участие в экспедиционных и исследовательских работах (гидротехнических и горно-межевых), являться действительным членом ЗСОИРГО, ООМИОСХ, Общества Сибирских инженеров, руководить Сибирским обществом техников, а также занимать официальные должности, например, производителя работ Томского переселенческого управления (Казак 2010: 50 - 56). За служебные заслуги и «за отлично-усердный и ревностный труд» Сборовский был пожалован орденом Св. Станислава III степени и памятной бронзовой медалью в память 300-летия царствования дома Романовых.

На позднеимперском этапе Н. А. Сборовского можно отнести к «молодому поколению» имперских экспертов, начинавших службу в ведомстве, к экспертам - практикам. Работа непосредственно на переселенческом участке в сочетании с активной общественно-политической позицией не позволяла реализовать эксперту Сборовскому свой научный потенциал. Критические, оппозиционные настроения по отношению к самодержавной власти, бюрократическому аппарату до революции сделали переход значительной части колонизационных экспертов на службу советской власти естественным.

Н. А. Сборовский - один из многих представителей российской интеллигенции с польскими корнями, который сознательно идет на сотрудничество с советскими организациями, более того становится на непродолжительный период второй половины 20 - начала 30-х гг. XX в. организатором научных и учебных начинаний в колонизационной сфере Сибири. В 1926 г. Сборовского приглашают на руководство вновь создаваемой кафедры при Сибирском институте сельского хозяйства и лесоводства. С 1927 г. Н. А. Сборовский с семьёй проживает в Омске. В Сибирском институте сельского хозяйства и лесоводства Сборовскому по зачёту большого количества изданных научных и научно-популярных работ, а также массы рукописных и лекционных переработок было присвоено звание профессора.

Более «академическую карьеру» в колонизационной сфере реализует столичный коллега Н. А. Сборовского заведующий отделом миграционных и колонизационных процессов Государственного научно-исследовательского института Л. И. Лубны-Герцык (Адамович, Бусько). В официальных биографиях он определяется как белорусский и российский ученый-экономист, родители которого были, возможно, белорусами. О «польскости» этого рода напишет одна из его известных представительниц писатель, переводчик Евгения Казимировна Герцык (1875 - 1944). «...не было спеси от недомыслия, не было любо- 
пытства к этому: не знаю, уж теперь не знаешь - с каких пор лишились всего и остались служить царям. Обрусели, забыли бесследно горечь национальной обиды, в женщинах ещё играла щебечущая польская прелесть, мужчины - в глубине хранили черты рыцарственности, все ещё из той же «Отчизны» (Герцык) Очевидно, что для художественной, интеллектуальной богемы даже советского периода древнее польское происхождение имело, в том числе, романтическую ценность, создавало дополнительные преимущества значимости и благородства. Все то, что не могло приветствоваться в среде советских чиновников, ученых, где пропагандировались интернациональные ценности нового рабоче-крестьянского государства. Мемуарист отметила и чиновничьи качества поляков: «Служа, не добивались чинов, всюду сохраняли некоторую независимость. Не от духовной свободы - от беспечности и барственного пренебрежения к карьеризму. Но служаки были исправные» (Герцык 10).

Общей чертой, характеризующей группу колонизационных экспертов, станут профессиональные заболевания. Выбирая в качестве места службы отдаленные азиатские и дальневосточные губернии, чиновники усиливали риск профессиональных заболеваний. Отсутствие медицинской помощи, постоянные разъезды в тяжелых бытовых условиях, сложная с психологической точки зрения обстановка решительно сокращала сроки службы переселенческих чиновников, негативно влияла на членов их семей. В прошении старшего производителя работ в Томском районе Н. А. Сборовского в качестве обоснования требуемого пособия на лечение жены отмечались - дороговизна сибирской жизни, «где уклад носит ясно выраженный колониальный характер» и отсутствие денежных сбережений (RGIA. Ф. 391. Оп. 7. Д. 3140 «О службе производителя работ Сборовского»). Суставной ревматизм (Августовского) стал основанием для перевода уже через два года из Амурской партии в Ставропольскую губернию. «Слабость, отдышка, боль в груди, ломота в верхних и нижних конечностях и скоро-преходящие боли с характером стреляющих» в сочетании с ослаблением зрения, проблемами ЖКТ, эмфиземой легких и атеросклерозом значатся в медицинской справке Ивана-Стефана Матвеевича Жебровского (RGIA. Ф. 391. Оп. 7. Д. 1186 «О службе производителя работ Жебровского Ивана»). Неутешительные диагнозы стали основанием завершения 49-летней государственной службы производителя работ Жебровского и ходатайства о пенсии по сокращенному сроку с предоставлением должности юрисконсульта по вольному найму. Тяжелая форма суставного ревматизма чиновника особых поручений, заведующего переселенческим делом в Атбасарском уезде Н. И. Дорожинского была «приобретена» во время служебной поездки по Петропавловскому уезду и вынужденной 12-ти часовой остановки в степи из-за бурана (RGIA. Ф. 391. Оп.7. Д. 1075 О службе чиновника особых поручений Дорожинского). В акте медицинского освидетельствования отмечался и ряд признаков сильнейшего нервного истощения пациента: «по малейшему поводу 
и часто без повода плачет, быстро раздражается». По рекомендации медиков начальник Переселенческого управления предоставил Дорожинскому отпуск на время лечения и пособие.

В воспоминаниях В. Ф. Романова отмечалось негативное влияние прессы на состояние здоровья и самочувствие чиновников, не имеющих возможности использовать ни публичные, ни судебные площадки для своего оправдания. Обострение политической ситуации и, на этом фоне национального вопроса, создавало благоприятные условия для националистической, левой прессы, усиливая при этом традиционное недоверие к бюрократам. «Поразительно легко относилась наша пресса к репутации и нервам чиновников: налжет, что-нибудь и даже не сочтет долгом исправить свою ошибку. Я уже не говорю о нашей оппозиционной прессе - та допускала заведомую ложь» (Романов 161). Обвинения в прессе Шликевича способствовали его нервному расстройству. «Сам он счел ниже своего достоинства опровергать возведенную на него клевету. Он просто начал плакать, без всякого иногда серьезного к тому повода. Увидит какого-нибудь старика со старухой, подумает, что и он с женой когда-нибудь будет так же беспомощен, и заплачет... К этому примешивается, конечно, обычный неврастенический страх» (Романов 161).

Отмеченные источниковедческие и методологические сложности выявления «польского элемента» в колонизационных структурах позднеимперской и раннесоветской России, тем не менее, не делают эту цель недостижимой. Польское участие в колонизационных учреждениях было оправдано перспективами карьерного роста, привлекательными материальными условиями и меньшей конкуренцией на азиатских окраинах. Служба в Сибири рассматривалась в качестве стартового этапа с возможным возвращением в будущем во внутреннюю Россию или на западные окраины. Для советской эпохи сибирские территории сохраняли привлекательность в связи с неочевидной политической безопасностью, по-прежнему наличием вакансий, в том числе в связи с открытием новых направлений учебных заведений.

При преобладании русского элемента, однозначно, что эта группа имела вполне интернациональный характер, усиливающийся в раннесоветское время. Кроме поляков выделяется немецко-прибалтийская группа, западно-славянская (чехи, сербы), встречались неожиданные французы и активно прибывающие в советский аппарат евреи.

Поляки-чиновники в рамках сформировавшейся группы колонизационных экспертов являлись носителями общих корпоративных и профессиональных черт. Интеграция в рамках административного аппарата при этом может рассматриваться не столько как русификация и утрата польскости, но приобретение дополнительных, например, социальных или профессиональных идентичностей (принадлежность/приобщение к русской интеллигенции/общерусскому освободительному движению/народникам/трудовому народу). 


\section{БИБЛИОГРАФИЯ}

Alishina, Galina. «Antinemeckaya kampaniya v gody Pervoj Mirovoj vojny v «centre» $i$ «na mestah» Rossijskoj imperii: realizaciya mer po bor'be s nemeckim zasil'em $v$ Tomskoj gubernii». Vestnik Tomskogo gosudarstvennogo universiteta. Istoriya. 2 (2016). S. 14 - 23.

Adamovich T. I. i dr. Vklad uchenyh BGU v razvitie ehkonomicheskogo obrazovaniya i ehkonomicheskoj mysli Belarusi. Minsk: BGU, 2002.

Gercyk, Evgeniya. Vospominaniya. M.: Direkt-Media, 2014.

Gorizontov, Leonid. Paradoksy imperskoj politiki: Polyaki v Rossii i russkie v Pol'she (XIX - nachalo XX v.). M.: Indrik, 1999.

Kazak N. «Imya v istorii kraya: Aleksandr Aleksandrovich Sborovskij». Istoriya Sibaki. [Elektronnyj resurs]: URL: http:/ / story-sibaka.ucoz.ru/index/0-146 (data dostupa: 10.09.2017)

Kazak, N. A. «Nauchnoe i literaturnoe nasledie N. A. Sborovskogo». Sbornik materialov k mezhdunarodnoj nauchnoj konferencii aspirantov $i$ studentov pri gumanitarnom fakul'tete OmGAU. 2010 god. Omsk: Izd-vo FGOU VPO OmGAU, 2010. S. 50-56.

Kaufman, Aleksandr. Pereselenie. Mechty i dejstvitel'nost'. M.: Tip. G. Lissnera i D. Sobko, 1906.

Konshin, Nikolaj. «Iz perezhitogo (Vospominaniya narodovol'ca)». Kraevedy Vostochnogo Kazahstana. Konshin Nikolaj YAkovlevich. 1864-1937. K 145-letiyu so dnya rozhdeniya. Ust'-Kamenogorsk, 2009.

Leonchik, Sergej. «Ostat'sya ili vernut'sya na rodinu? K voprosu ob ostavshihsya posle amnistii na territorii Enisejskoj gubernii ssyl'nyh pol'skih povstancah 1863 - 1864 g.». Sibirskaya ssylka: sb. nauch. st. Irkutsk: Izd-vo «Ottisk», 2017. Vyp. 8 (20). S. 307 - 329.

Mathanova, Natal'ya. «Polyaki na gosudarstvennoj sluzhbe v Sibiri: problemy integracii do i posle YAnvarskogo vosstaniya». Problemy rossijsko-pol'skoj istorii i kul'turnyj dialog: materialy Mezhdunarodnoj konferencii. Novosibirsk, 2013. S. 133 - 142.

Moiseenko, Valentina. «Krest'yanskie pereseleniya v 1920-e gody (iz istorii migracii v Rossii)». Demograficheskoe obozrenie. 2015. T. 2. № 3. S. 87 - 141.

Mulina, Svetlana. «Pol'skoe chinovnichestvo na rossijskoj sluzhbe». Social'no-ehkonomicheskoe razvitie $i$ istoriko-kul'turnoe nasledie Tarskogo Priirtysh'ya: Materialy VI regional'noj nauchno-prakticheskoj konferencii, posvyashchennoj 120-letiyu so dnya rozhdeniya A. V. Vaganova (g. Tara, 1 - 2 marta 2012 g.). Omsk: OOO «Amfora», 2012. S. 108-112.

Naumova, Natal'ya. "Polyaki-zheleznodorozhniki v osvoenii Transsibirskoj magistrali (pervaya chetvert' XX v.)». Chelovek - Tekst - Ehpoha. Vyp. 3. Sociokul'turnye aspekty osvoeniya Sibiri. Tomsk, 2008. S. 143 - 159.

Oplakanskaya, Renata. «Polyaki na gosudarstvennoj sluzhbe v Sibiri vo vtoroj chetverti XIX v.». Mezhregional'naya nauchno-prakticheskaya konferenciya. Abakan, 2003. S. 172 - 176.

Ostrovskij, Leonid. Polyaki v Zapadnoj Sibiri v konce XIX - pervoj chetverti XX veka: Diss. d.i.n. Novosibirsk, 2014.

Hanevich, Vasilij. Polyaki v Tomske (XIX - XX vv.): biografii. Tomsk: Izd-vo Tomskogo gos. ped. un-ta, 2012.

Remnev, Anatolij. «Politicheskaya ssylka i zapadnosibirskaya administraciya (1863 - 1868 gg.)». Obshchestvenno-politicheskoe dvizhenie i kul'turnaya zhizn' Sibiri (XVIII - XX vv.). Omsk, 1996.S. 29 - 43. 
НАТАЛЬЯ СУВОРОВА, «ПОЛЬСКИЙ ЭЛЕМЕНТ» В КОЛОНИЗАЦИОННЫХ СТРУКТУРАХ...

Romanov, Vladimir. Starorezhimnyj chinovnik. Iz lichnyh vospominanij ot shkoly do ehmigracii, 1874-1920 gg. SPb.: Nestor-Istoriya, 2012.

Rynkov, Vadim. «Pereselenie, kolonizaciya, spasenie golodayushchih: proekty i realizaciya pereselencheskoj politiki v pervoe poslerevolyucionnoe pyatiletie». Proekty osvoeniya i razvitiya Sibiri v XX veke. Novosibirsk, 2013. S. 108 - 137.

Tatishchev, Aleksej. Zemli i lyudi: V gushche pereselencheskogo dvizheniya (1906 - 1921). M.: Russkij put', 2001. 